\title{
Analysis of Police Culture through Use of OCAI Model
}

\author{
Monika Pajpachová, Iveta Nováková \\ Academy of the Police Force in Bratislava, Slovakia \\ monika.pajpachova@minv.sk \\ iveta.novakova2@minv.sk
}

\begin{abstract}
The study presents analysis of police culture as one of determinants of a police organisation's success. For this purpose the authors have used a diagnostic instrument of competing values, the so-called OCAI model. They present original scientific findings - outcomes of a scientific and research project entitled "The Success Factors of the Police Organisation" (No. 185). The project was carried out by the Management and Information Science Department of the Academy of the Police Force in Bratislava and commissioned by the Section of Personal and Social Activities and Personnel Department of the Ministry of Interior of the Slovak Republic.

Keywords: culture, police culture, OCAI model, hierarchy culture, clan culture, market culture, adhocracy culture.

\section{Introduction}

Every organisation has its particular characteristic signs which are specific and unique to it $[14,37-40]$. This notably corresponds to the police environment as well [23]. Knowledge of organisational culture signs [18], its strong and weak points reinforce the regulation of effective leadership [2], promote efficiency and handling of circumstances in order to reach goals and exceed citizens' as well as institutions' expectations. Perception and knowledge of these signs is a very demanding process; it calls upon interpretation and understanding of manifested features and elimination of negative ones. One possibility of how to identify the elements of organisational culture is to use typology models. Literature offers a large scale of these typologies, the most accepted are related to $[11,76]$ :
\end{abstract}


- organisational structure;

- environmental impact and organisation's reaction;

- tendencies in organisation's behaviour.

A research team was facing a challenge which of the models should have been used in order to identify the features of police culture. A long-lasting discussion ended with a model developed by Robert E. Quinn and Kim S. Cameron. The OCAI model of the Competing Values Framework (CVF) consists of four Competing Values that correspond with four types of organisational culture and belongs to the second group of the above mentioned typologies. (It is necessary to underline that there is not a good or bad answer in OCAI questionnaire.) Its mission is to provide a picture about the existing and preferred type of organisational culture. The results obtained by a comparison may be used when measuring changes of organisational culture. Every organisation has its own combination of these four types of organisational culture.

The model is said to be one of the most significant models in identifying features of organisational culture. Moreover, it may be used to assess communication [20], managerial skills, organisational changes, leadership, key competences [1], human resources management [12, 102-119], TQM and many other aspects [3]. The authors of the CVF model interpret that organisational culture is a critical factor for effective [19] and longterm success of organisation $[11,63]$.

\section{Dimensions of CVF model}

Dimension of structure. It takes into account such indicators of effectiveness for organisation as stability, order, constant duration, control and flexibility; cohesion, universality and discretion on the other side. They act as opposites to continuum. One organisation may be effective in terms of quick and flexible reaction towards environmental changes and the other organisation may benefit from a long-term stability and predictability.

Dimension of focus. A horizontal dimension maps a degree to which an organisation focuses inwards or outwards. "Some organizations are perceived effective when their internal rules are harmonized and unified, others are perceived effective if they focus on interaction and competitions with other companies" [21,363]. An internal focus is valid in environments where competition or customer focus is not the most important thing, but in competitive climates or where external stakeholders hold sway, this challenge must be met directly.

The first dimension illustrates that certain organisations are more effective if they perform in flexible and dynamic manners, focusing on a change. In contrast, other organisations are effective when they focus on stability, order and control. Criteria determined by the second dimension focus on internal indicators, integration and unity as well as external indicators where differentiation and competition play a big role. Quadrants reached by a combination of the above presented dimensions feature certain specific 
objectives (constituting a core content of an organisation) and tools. The third dimension is a mean-ends continuum on the degree of closeness to desired organisational outcomes. This dimension defines the behaviour that the outcomes (beliefs, assumptions and values) from the four culture types achieve. The four quadrants identified by the authors represent the four basic types of organisational culture - determinants of effective organizational performance. Consequently, each of the four quadrants identifies a certain set of indicators of effectiveness for organization (Figure 1) [11, 61]. Police environment may be perceived effective even though there are no significant changes. This environment is characteristic for its long-term organisational structure, systems and ongoing processes; it features a high level of stability and control.

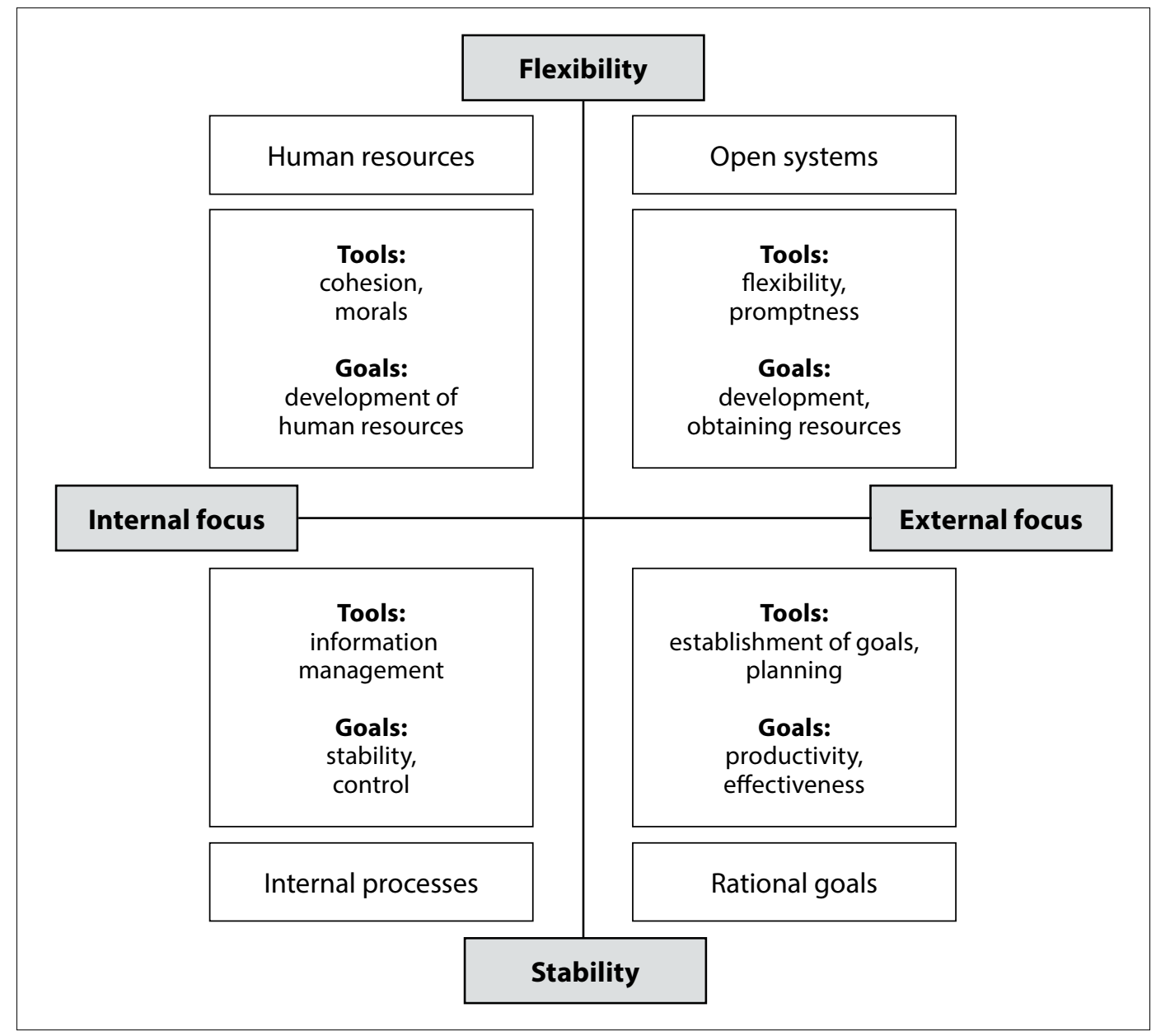

Figure 1. Model of organizational effectiveness 
Values that constitute opposites of a continuum are competitors. By combining separate dimensions we will attain competing quadrants along a diagonal. Each quadrant is made of a distinct set of indicators. These indicators of effectiveness represent what people value about an organisation's performance. They define what is seen as good and right and appropriate. In other words, they define the core values, based on which judgments about organisations are made.

OCAI typology classifies organisational culture into clan, adhocracy (innovative), market and hierarchy. Clan culture: This working environment is friendly. The goals should be defined in terms of mutual respect, concern for people, and a healthy internal climate, optimal health and wellness on a personal level as well as for employees. Adhocracy culture: This is a dynamic and creative working environment. Employees take risks. Leaders are seen as innovators and risk takers. Experiments and innovation are the bonding materials within the organisation. Prominence is emphasised. Long-term goal is to grow and treat new resources. The organisation promotes individual initiative and freedom. Market culture: This is a results-based organisation that emphasizes finishing work and getting things done. People are competitive and focused on goals. The emphasis on winning keeps the organisation together. Reputation and success are most important. Hierarchy culture: This is a formalised and structured working environment. Procedures decide what people do. Keeping the organisation functioning smoothly is most crucial. Formal rules and policy keep the organisation together. Long-term goals are stability and results, paired with efficient and smooth execution of tasks.

Organisational cultures shown in the model diagonally represent the opposites; neighbouring dimensions have certain opposite as well as certain common indicators.

\section{Aim}

The aim of the article is to identify and analyse features of police culture in Slovakia with the use of the OCAI model and to point out those elements and areas which require further consideration.

\section{Methods}

Police culture has been analysed through the use of

- general methods such as analysis, synthesis, comparison, deduction, theory and experience generalization;

- specific methods such as OCAI*.

\footnotetext{
* Organizational Culture Assessment Instrument (Cameron, Quinn, 1999).
} 


\section{Dimensions of OCAI model - interpretation of the research results}

As already mentioned, an OCAI model has been used for the analysis of organisational culture of the Police Force in Slovakia. Data were analysed by summing the points sub-allocated by respondents to the questionnaire items. Item A stands for clan culture, item B stands for adhocracy culture, item C stands for market culture and item D stands for hierarchy culture. This study focuses on the analysis of six OCAI dimensions as well as comprehensive organisational culture. The results are interpreted separately for a current and preferred organisational culture; however, conjointly. Although quantitative data was obtained from 499 questionnaires, some were not complete - missing information referred to OCAI questionnaire dimensions or all dimensions. In case all 499 respondents had reported, according to OCAI questionnaire, each dimension would have been allocated 49,900 points, i.e. 100 points per respondent. The data was analysed using gross scoring, i.e. total number of points for total culture should equal 299,400 for a current and preferred culture. As mentioned, a few respondents did not express their opinion on a current or a preferred type of culture. We managed to obtain 272,070 points for a current state and 272,365 points for a preferred culture.

This instrument facilitates to assess six subsystems dimensions of organisational culture:

- dominant characteristics;

- organisational leadership;

- management of employees;

- organisational glue;

- strategic emphasis;

- criteria of success.

These dimensions may be assessed from two viewpoints:

- current - actual culture;

- preferred culture.

Current culture reflects present state of play - existing culture in a police organisation. In comparison, preferred culture emphasises future culture, i.e. ideal culture preferred by police personnel. 
Monika Pajpachová, Iveta Nováková. Analysis of Police Culture through Use of OCAI Model

\section{Dominant characteristics of organisation}

A dimension which illustrates a focus of organisational culture onto clan ("family"), adhocracy (dynamic working environment where employees are kept together by commitment and responsibility), market (emphasis on reaching goals) or hierarchy culture (strict formal rules). Actual dominant characteristics are shown in Table 1 and Figure 2.

Table 1. Comparison between current and preferred state of the dimension "Dominant characteristics"

\begin{tabular}{|c|l|}
\hline $\begin{array}{c}\text { Current } \\
\text { state }\end{array}$ & $\begin{array}{l}\text { A quantitative analysis of obtained data confirmed that members of the Police Force } \\
\text { perceive their organisation as a hierarchy type (19200 p.) with certain market features } \\
\text { (12940 p.). The results indicate that the organization is managed by hierarchy and } \\
\text { market organisation rules impeding dynamic cultures (adhocracy and clan). }\end{array}$ \\
\hline $\begin{array}{c}\text { Preferred } \\
\text { state }\end{array}$ & $\begin{array}{l}\text { The results indicate that police officers would welcome the environment of mutual } \\
\text { trust, coherence, more informal relations and atmosphere - features typical for clan } \\
\text { culture (16040 p.). Nevertheless, they would also support hierarchy culture which } \\
\text { emphasizes rules, strict adherence to norms and procedures. Such characteristics are } \\
\text { typical for (police) organisation which shall guarantee protection and security. }\end{array}$ \\
\hline
\end{tabular}

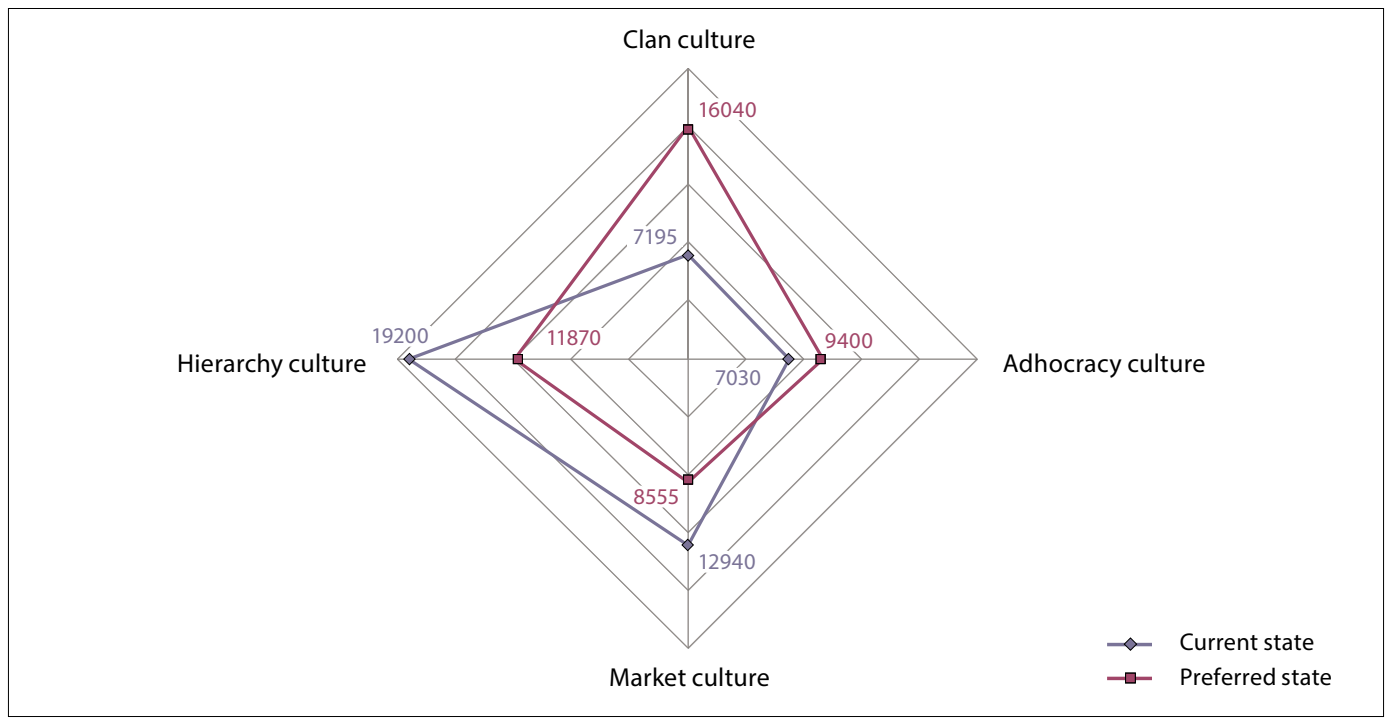

Figure 2. Dominant characteristics 
Monika Pajpachová, Iveta Nováková. Analysis of Police Culture through Use of OCAI Model

\section{Organisational leadership}

A dimension emphasising leadership depicts four leadership forms: leadership focusing on support and assistance (clan culture), leadership focusing on innovation and willingness of employees to take risk (adhocracy), leadership focusing on aggressive reaching of goals (market culture), leadership focusing on smooth functioning of organisation and coordination of processes (hierarchy). An actual organisational leadership is shown in Table 2 and Figure 3.

Table 2. Comparison between current and preferred state of the dimension "Organisational leadership"

\begin{tabular}{|c|l|}
\hline $\begin{array}{c}\text { Current } \\
\text { state }\end{array}$ & $\begin{array}{l}\text { Market culture (emphasises reaching goals and results }-17405 \mathrm{p} \text {.) and hierarchy culture } \\
\text { (underlines smooth functioning and careful control }-14750 \text { p.) are dominant cultures } \\
\text { in the police organisation. }\end{array}$ \\
\hline $\begin{array}{c}\text { Preferred } \\
\text { state }\end{array}$ & $\begin{array}{l}\text { The police personnel expect that the functioning of the police organising will be } \\
\text { provided by effective coordination of processes - a feature typical for hierarchy culture } \\
\text { (16325 p.). Fulfilment of tasks, besides others, requires managerial trust in employees, } \\
\text { their support and loyalty what is reflected in clan culture. }\end{array}$ \\
\hline
\end{tabular}

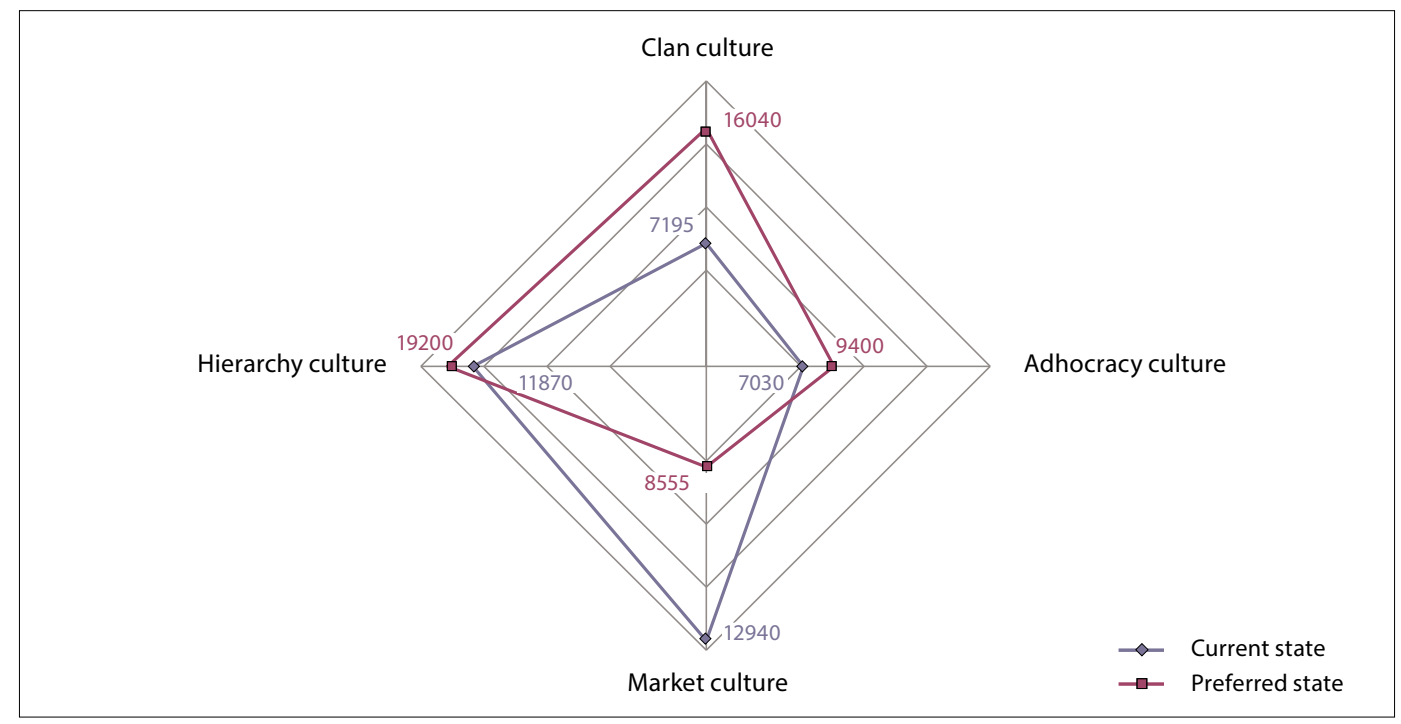

Figure 3. Organisational leadership 


\section{Management of employees}

It is a dimension which illustrates how members of the Police Force are engaged in work. Similarly to previous two dimensions, we also distinguish four possible approaches here. Clan approach refers to participation, team work and consensus. Adhocracy emphasises originality and innovation. Market culture is defined by high requirements, competitiveness and reaching goals. Predictability, stability in relationships and safety of employees are indicators of hierarchic culture. An actual management of employees is shown in Table 3 and Figure 4.

Table 3. Comparison between current and preferred state of the dimension "Management of employees"

\begin{tabular}{|c|l|}
\hline $\begin{array}{c}\text { Current } \\
\text { state }\end{array}$ & $\begin{array}{l}\text { The results suggest that members of the Police Force tend to emphasise reaching } \\
\text { goals, establishing high requirements and competitiveness which is typical for market } \\
\text { culture (15715 p.). The second position belongs to hierarchy (11020 p.) which features } \\
\text { emphasis on safety of employees, creating stabile relationships and prediction of } \\
\text { future development. }\end{array}$ \\
\hline $\begin{array}{c}\text { Preferred } \\
\text { state }\end{array}$ & $\begin{array}{l}\text { It is obvious that police officers prefer team work, participation and mutual agreement- } \\
\text { typical characteristics of clan culture (15215 p.). An interesting finding refers to } \\
\text { their desire to even stronger emphasise hierarchy, e.g. through a higher stability in } \\
\text { relationships. }\end{array}$ \\
\hline
\end{tabular}

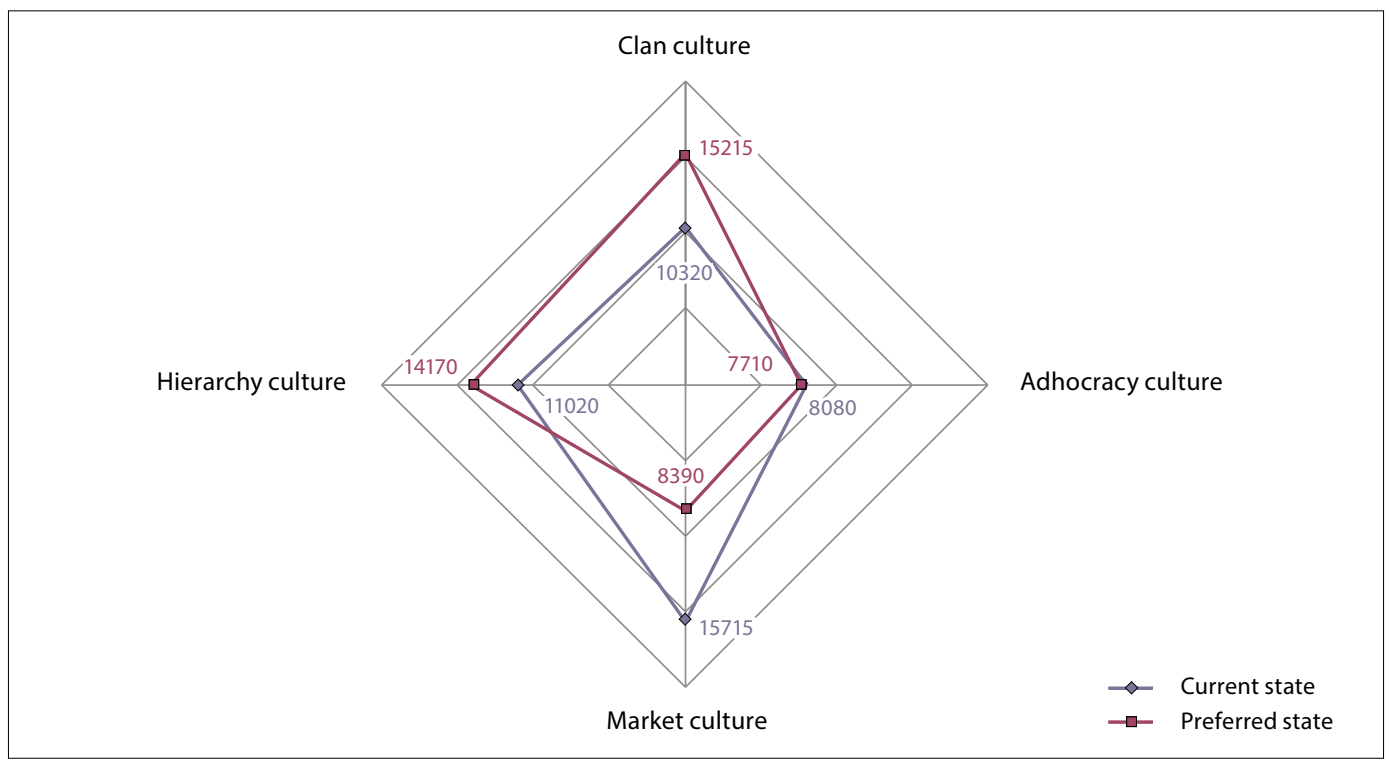

Figure 4. Management of employees 
Monika Pajpachová, Iveta Nováková. Analysis of Police Culture through Use of OCAI Model

\section{Organisational glue}

It is a dimension which keeps organisation together. This approach emphasises mutual trust and supports commitment - typical features of clan culture. As to adhocracy factors which keep organisation "together", the most important are experimenting, innovation, development and continuous improvements. Market culture organisations are kept together by achievements, reaching goals and success. In hierarchy culture, glue refers to formal rules and smooth functioning. Actual organisational glues are shown in Table 4 and Figure 5.

Table 4. Comparison between current and preferred state of the dimension "Organisational glue"

\begin{tabular}{|c|l|}
\hline $\begin{array}{c}\text { Current } \\
\text { state }\end{array}$ & $\begin{array}{l}\text { Features such as mutual trust (clan culture), experimenting, innovative approaches } \\
\text { and creativity (adhocracy) are not the priority. The police organisation is kept together } \\
\text { by strict adherence to organisational rules and principles which is a typical indicator } \\
\text { of hierarchy culture (17365 p.) and by reaching goals and success - market culture } \\
(12640 \text { p.). }\end{array}$ \\
\hline $\begin{array}{c}\text { Preferred } \\
\text { state }\end{array}$ & $\begin{array}{l}\text { Police personnel would prefer "glue elements" such as mutual trust and loyalty - clan } \\
\text { culture (17150 p.). Yet, they consider important hierarchy culture (9770 p.), innovation } \\
\text { and development culture - adhocracy }(9070 \text { p.) and market culture - efficiency and } \\
\text { success }(8725 \text { p.). }\end{array}$ \\
\hline
\end{tabular}

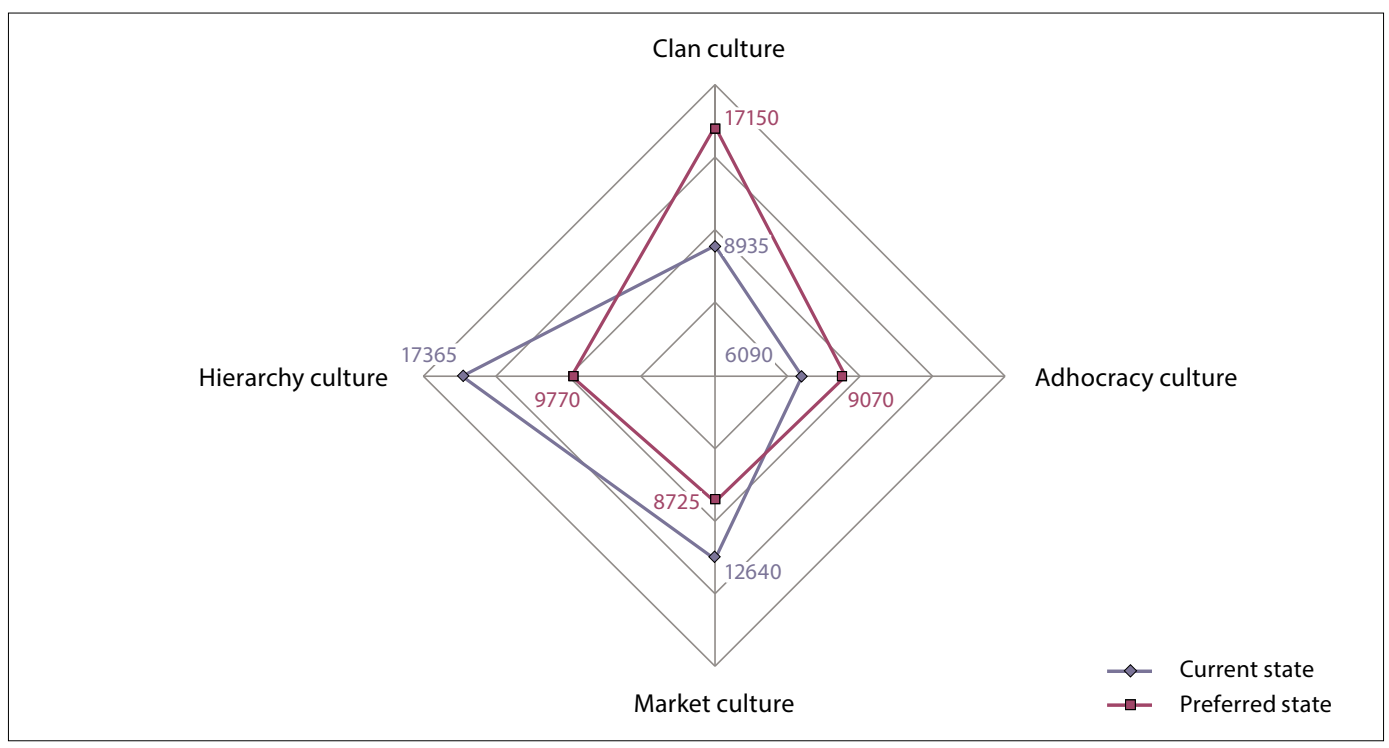

Figure 5. Organizational glue 


\section{Priority strategic factors - strategic emphasis}

Emphasis is placed on factors which indicate what an organisation pinpoints from a long-term perspective. According to a model of competing values, an organisation may give prominence to human resources development, broad-mindedness and mutual trust (clan culture). Organisations which prefer (from a long-term perspective) creativity, innovation, new challenges symbolize adhocracy culture. Emphasizing setting long-term goals and reaching success are features of market culture. An organisation may put a strategic emphasis on stability, systematic control, and smooth performance - typical features of hierarchy culture. Actual priority strategic factors - strategic emphasis are shown in Table 5 and Figure 6.

Table 5. Comparison between current and preferred state of the dimension "Priority strategic factors"

\begin{tabular}{|c|l|}
\hline $\begin{array}{c}\text { Current } \\
\text { state }\end{array}$ & $\begin{array}{l}\text { The police organisation put a strategic emphasis on stability, efficiency, control over } \\
\text { fulfilment of tasks and ensuring smooth functioning - typical features of hierarchy cul- } \\
\text { ture }(16340 \text { p.). Moreover, emphasis is put on establishment and reaching long-term } \\
\text { goals and success (clan culture - } 13895 \text { p.). }\end{array}$ \\
\hline $\begin{array}{c}\text { Preferred } \\
\text { state }\end{array}$ & $\begin{array}{l}\text { There is an evident discrepancy between a current and preferred state. Market and } \\
\text { hierarchy cultures are represented to a lowest degree. Police personnel would prefer } \\
\text { more trust, broad-mindedness, cooperation and friendly environment - clan culture } \\
\text { (15250 p.). They would also prefer that management support innovation, originality, } \\
\text { search for new challenges - adhocracy culture. }\end{array}$ \\
\hline
\end{tabular}

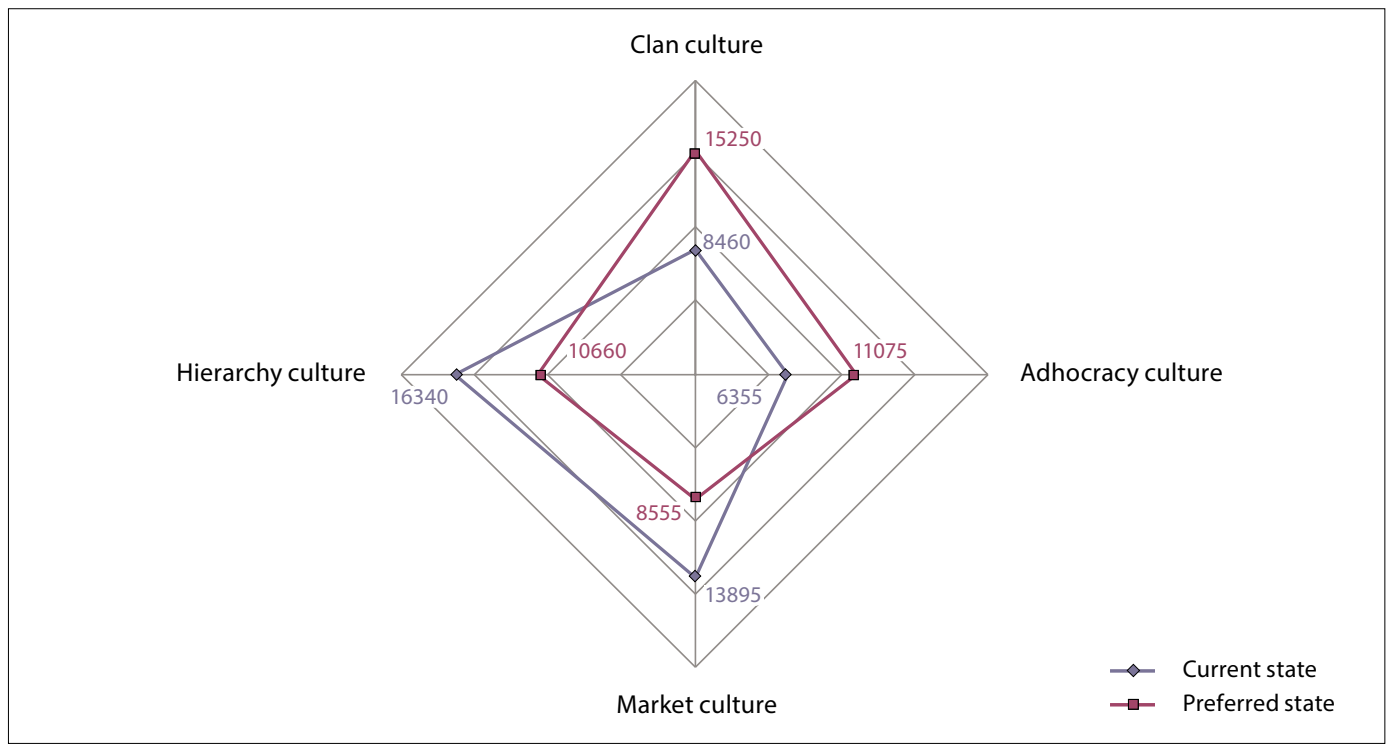

Figure 6. Priority strategic factors - strategic emphasis 


\section{Criteria of success}

A model of competing values, in addition, illustrates how an organisation defines successiveness. Likewise, this dimension distinguishes four cultural types. Successiveness maybe defined by means of human resources development, team work and employees' trust which is typical for clan culture. It may also be defined through uniqueness of provided services (products) and innovations (adhocracy culture). Market culture defines success by reaching a dominant position on the market and determined goals; in hierarchy culture it is conditioned by effective, responsible and reliable provision of services (products). Actual criteria of success are shown in Table 6 and Figure 7.

Table 6. Comparison between current and preferred state of the dimension "Criteria of sucess"

\begin{tabular}{|c|l|}
\hline $\begin{array}{c}\text { Current } \\
\text { state }\end{array}$ & $\begin{array}{l}\text { According to respondents, the main focus is placed on reliable and responsible provi- } \\
\text { sion of services within a legislative framework, fulfilment of agenda and smooth and } \\
\text { effective service (hierarchy culture }-16785 \text { p.). In addition, reaching fixed goals and } \\
\text { long-term success is emphasised (market culture). }\end{array}$ \\
\hline $\begin{array}{c}\text { Preferred } \\
\text { state }\end{array}$ & $\begin{array}{l}\text { Respondents would prefer so-called "soft factors" as criteria of success, e.g. human } \\
\text { resources development, team work, participation and loyalty etc. (clan culture - } \\
17390 \text { p.). The results indicate that respondents are aware of the significance of } \\
\text { hierarchy culture in terms of organisational success - effective, thorough, smooth and } \\
\text { stable performance of service. }\end{array}$ \\
\hline
\end{tabular}

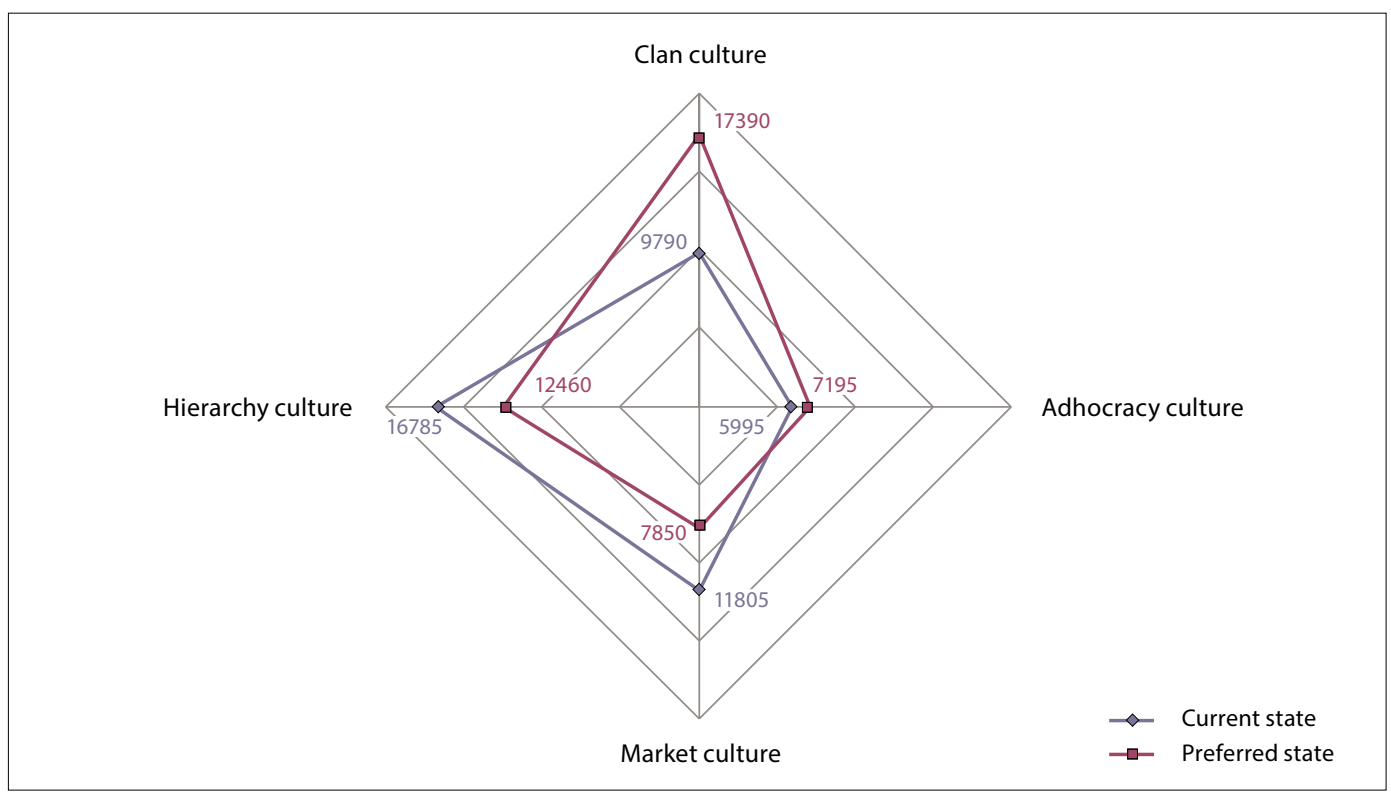

Figure 7. Criteria of success 
According to Cameron and Quinn, the specified content components include those aspects of organisational culture which facilitate identification of basic values and implicit assumptions as regards to organisational effectiveness [11, 105].

\section{Assessment of comprehensive organisational culture through the use of the OCAI model}

The presented results shown in Table 7 and Figure 8 illustrate how police culture is assessed by respondents - hierarchy and market culture dominate. On the other hand, respondents would prefer clan culture elements. Though, they are aware of the fact that hierarchy culture is a typical culture for security systems [10, 123-134].

Table 7. Comparison between current and preferred state of the dimension "Comprehensive organisational culture through the use of the OCAI model"

\begin{tabular}{|c|c|}
\hline $\begin{array}{l}\text { Current } \\
\text { state }\end{array}$ & $\begin{array}{l}\text { From the perspective of comprehensive assessment of organisational culture in } \\
\text { the police organisation the research shows that hierarchy culture is dominant ( } 95460 \mathrm{p} \text {.). } \\
\text { It points out formal and structural elements, emphasizes processes, orders, regulations- } \\
\text { organisational norms. The organisation is glued together by formal rules. Leaders are } \\
\text { good coordinators and organisers. Emphasis is put on smooth functioning, reaching } \\
\text { the right performance, stability, efficiency, control over fulfilment of tasks. Success is } \\
\text { determined by stable provision of services, fulfilment of tasks established in planning } \\
\text { documents, minimising costs. Along with this, market culture has also quite a good } \\
\text { position in the police organisation ( } 84400 \text { p.). It is typical for organisations oriented } \\
\text { at results and reaching measurable goals which are considered as criteria of success. } \\
\text { Leaders push their employees towards efficient performance, they are strict, require } \\
\text { accuracy and support competitiveness. The police organisation is glued together by } \\
\text { marked achievements. }\end{array}$ \\
\hline $\begin{array}{l}\text { Preferred } \\
\text { state }\end{array}$ & $\begin{array}{l}\text { As reported by respondents, police personnel would prefer organisational type } \\
\text { of culture which has much in common with clan culture ( } 96035 \text { p.). Such cultural type } \\
\text { resulted from similarities with family-oriented organisations. A dominant position } \\
\text { belongs to friendly working environment and atmosphere. Essentials of this culture } \\
\text { are: sharing values and goals, coherence, solidarity, team mind, awareness of "us", } \\
\text { caring, human resources development, trust, and broadmindedness. These features } \\
\text { are considered the key criteria of success. Leaders support their employees; empha- } \\
\text { size cooperation, participation and consensus. An organisation featuring clan culture } \\
\text { is glued together by loyalty, mutual trust and commitment. Though, the results show } \\
\text { that members of the Police Force are aware of the fact that a hierarchy organisation } \\
\text { must personalise certain elements of hierarchy culture ( } 75255 \text { p.). }\end{array}$ \\
\hline
\end{tabular}




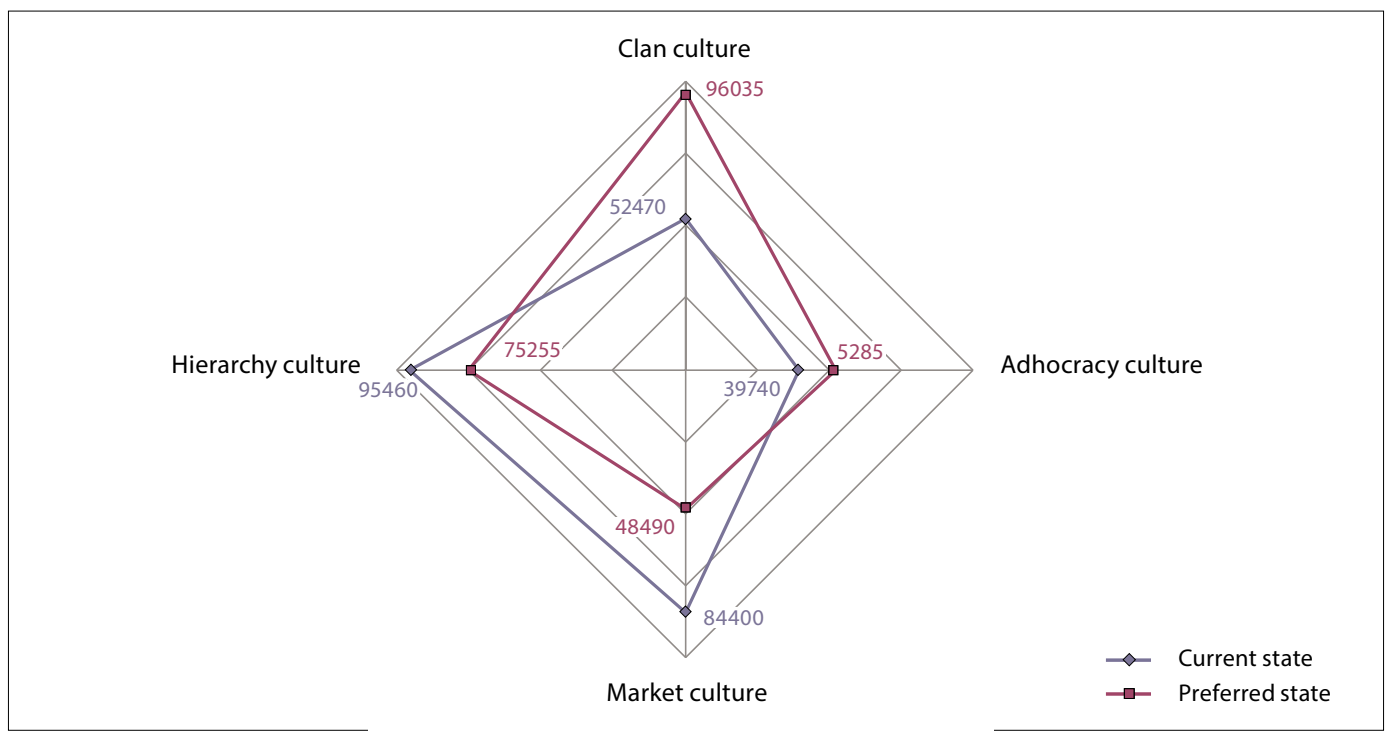

Figure 8. Comprehensive organisational culture of the police organisation through the use of the OCAI model

"Healthy" police culture contributes to the enhancement of employees' fellowship, employees' identification with an organisation, it challenges the decision-making process and implementation of plans and processes, improves communication, participation of employees in organisation's management, motivation, loyalty, efficacy, stability and integrity, determines clear rules of behaviour and decreases control obligations. The aim of police culture is to make police officers act according to organisation's standards which lead towards prosperity and promoting a good reputation.

\section{Conclusions}

A very title of the institution - Police Force - indicates that it is constituted by a force - collective. The main effort is a concept of common strength, reaching fixed goals in close cooperation with citizens and institutions - public which provide certain services [16]. One crucial success prerequisite is an acceptable, clear and explicit police culture which in addition affects a comprehensive performance [9] and meets police's needs. Organisational culture manifests not only the way how goals are reached, but its typical indicators are also e.g. a possibility do decide, control [22], communication [15] or motivation mechanism, preferred values, members' behaviour, character of cooperation [20], management of processes and many others which have been discussed in the article and which illustrate a picture of police culture [14,39-42]. The culture is, as 
it is apparent from one of the OCAI model dimensions "criteria of success", an important factor of organisation's successiveness and at the same time it represents a special sub-system of a police organisation affecting its internal activities [7]. It is evident that a continuous support is a must in order to create an effective working environment since no one may require applying the organisational culture - employees have to get used to it. This culture defines basic organisational values and shows employees the right and correct approaches, ways of thinking and acting, it contributes to a feeling of identity and supports their commitment for over-personal values. It enhances organisational stability and helps to understand organisational changes and activities.

\section{Policijas kultūras analīze, izmantojot OCAI modeli}

\section{Kopsavilkums}

Pētījumā analizēta policijas kultūra kā viens no faktoriem, kas nosaka policijas kā organizācijas pēctecīgumu. Šim nolūkam autori ir izmantojuši diagnostikas instrumentu kompetences vērtībām, tā saucamo OCAI modeli. Tas uzrāda oriǵinālus zinātniskos atklājumus - balstītus uz zinātniskās un pētniecības projekta "Panākumu faktori policijas organizācijā" (Nr. 185) rezultātiem. Projekts tika veikts, sadarbojoties Policijas akadēmijai Bratislavā un Slovākijas Republikas Iekšlietu ministrijai.

Atslēgvārdi: kultūra, policija kultūra, OCAI modelis, kultūras hierarhija, klanu kultūra, tirgus kultūra, inovāciju kultūra.

\section{References}

1. Baričičová, L. Kompetencie policajných manažérov. Bratislava: Academy of the Police Force, 2011, 160.

2. Baričičová, L. Analýza determinantov riadenia policajnej organizácie. Policajná teória a prax [Bratislava: Academy of the Police Force]. 2011, (1), 5-23.

3. Binderová, M. Špecifická vyučovacieho procesu v profesijnom cudzojazyčnom vzdelávaní. In: Súčasnýstav a trendy rozvoja teórie spoločenskovedných disciplín a praxe ich výučby na školách s bezpečnostno právnym zameraním. Bratislava: Academy of the Police Force, 2010, 22-29.

4. Cameron, K. S., Quinn, R. E. Diagnosing and Changing Organizational Culture. San Francisco: Jossey-Bass, 2006, 242.

5. Crank, J. P. Understanding Police Culture. United States: Anderson Publishing Co, 2004.

6. Ethic code of a member of the Police Force.

7. Ferenčíková, P., Števánková, D. Nenahraditel’nost' "l’udskéhoelementu" v IKT pri výučbe cudzích jazykov. In: Cudziejazyky v Európskejúnii III. Bratislava: Academy of the Police Force, 2012, 28-29. 
8. Goldsmith, A. Taking police culture seriously: Police discretion and the limits of law. Policing and Society. 1990, 1(2); 91-114.

9. Jurisová, M. Legislatívne východiská prevencie kriminality a inej protispoločenskej činnosti v podobe zákona č. 583/2008 Z. z. o prevencii kriminality a inej protispoločenskej činnosti. In: Prevencia kriminality - výzva spoločnosti. Bratislava: Academy of the Police Force, 2013, 67-73.

10. Kostrec, M. Legislatíva, štandardy a normyplatné pre oblast' auditu informačných systémov. Policajná teória a prax [Bratislava: Academy of the Police Force]. 2011, (2), 123-134.

11. Lukášová, R., Nový, I. et al. Organizační kultura. Praha: Grada Publishing, 2004, 176.

12. Mezei, J. Právna povaha štátnej služby. In: Aktuálne otázky súkromného práva a ich priemet do vyučovacieho procesu. Bratislava: Academy of the Police Force, 2013, 102-119.

13. Müller, D. Kultura organizace je cestou ke strategii. Praha: Management Press, 2013, 267.

14. Murdza, K. Policajná kultúra. Policajná teória a prax [Bratislava: Academy of the Police Force]. 2009, (1), 37-48.

15. Nováková, I. et al. E-learning a jeho aplikácia v odbornom jazykovom vzdelávaní pre vybrané policajné služby. Bratislava: Academy of the Police Force, 2015, 177.

16. Ondicová, M., Dworzecki, J. Pocit bezpečia občanov v mestách Trnava a Slupsk - komparácia čiastkov ýchvýsledkov medzinárodnej VVÚ. Policajná teória a prax [Bratislava: Academy of the Police Force]. 2014, (3), 20-38.

17. Ondrejkovičová, J., Masárová, M., Miženková, L. Deutsch im Beruf-Polizei. Bratislava: Academy of the Police Force, 2014, 179.

18. Pajpachová, M. Modely organizačnej kultúry ako východisko poznávania policajnej kultúry. Policajná teória a prax [Bratislava: Academy of the Police Force]. 2012, (2), 5-21.

19. Pajpachová, M. et al. Faktory úspechu policajnej organizácie. Project of a scientific and research task No. 185. Bratislava: Academy of the Police Force, 2013, 47.

20. Pastuchová Neumannová, A. Sociálna komunikácia vo verejnej správe. In: Racionalizácia verejnej správy. Bratislava: Academy of the Police Force, 2016, 315-321.

21. Quinn, R. E., Rohrbaugh, J. A spatial model of effectiveness criteria. Towards a competing values approach to organizational analysis. Management Science. 1983, (29), 363-377.

22. Sabayová, M. Medzinárodná výmena informácií - jeden z klúčových aspektov eliminácie daňových únikov. In: Odhal’ovanie daňových únikov a daňovejtrestnej činnosti. Plzeň: Vydavatelství a nakladatelství Aleš Čeněk, 2013, 67-79.

23. Sobihard, J., Andorová, P. et al. Policajná správa. Plzeň: Vydavatelství a nakladatelství Aleš Čeněk, 2013, 246.

24. Act No. 171/1993 Coll. on the Police Force as amended.

25. Act No. 73/1998 Coll. on State Service of members of the Police Force, of the Slovak Information Service, of the Corps of Prison Wardens and Judicial Guards of the Slovak Republic and of the Railway Police, as amended. 